\title{
The fight against gender-based violence: A missional nurturing of people of peace
}

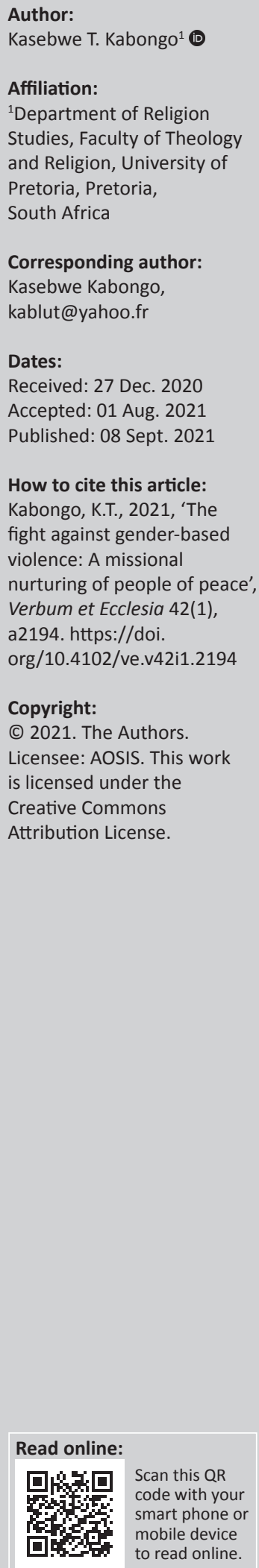

The fight against gender-based violence (GBV) requires the participation of as many society stakeholders as possible, including the church. Gender-based violence has become a pandemic in South Africa. The township of Soshanguve where InnerCHANGE, a missional team, serves is just a microcosm of this alarming reality. This research uses the grounded theology methodology to design a curriculum to empower teenagers and the youth to become people of peace. These are people who commit to act non-violently in all circumstances and to call out violence as a society destroyer. This study stresses that perpetrators and enablers of GBV are the causes of the pandemic. The perpetrators are known to be mostly men. The enablers are the situation of the normalisation of violence in local communities, a negative understanding of power and a lack of participation from the church in fighting against GBV. This study focuses on enablers for the development of people of peace. The aim for InnerCHANGE was to participate in this fight against GBV in teaching teenagers and the youth to see violence as abnormal, to understand power as a resource to serve others and to actively participate in this fight against GBV through their everyday choices of acting nonviolently and calling out violent acts. The research concludes that GBV seems to be intergenerational in our local community. And, it will take preventive measures such as the education of teenagers and the youth to break such a normalised abuse and build peaceful communities where violence will not be tolerated.

Intradisciplinary and/or interdisciplinary implications: This article is located in the field of missiology. It is inspired by practical theology, sociology, psychology and journalism to design a curriculum that intends to develop the youth and teenagers as people of peace.

Keywords: normalisation; people of peace; power; violence; participation.

\section{Introduction}

Gender-based violence (GBV) is 'experienced by one-third of women globally' (Amusa, Bengesai \& Khan 2020:1). It is considered as a pandemic in South Africa. The National Development Plan (NDP) of South Africa recognises that GBV 'is unacceptably high with South Africa having the highest rates of violence against girls and women in the world' (Yamile 2020:2). The township of Soshanguve, the place where the author lives in, seems to be a microcosm of the high prevalence of GBV. Townships have a history of violence from the time of their inceptions. Their original residents were migrant labourers who moved to urban areas in search of jobs. They camped around cities and towns in informal settlements. At some point, violence was used to remove them from these informal settlements around cities and towns to place them in townships as the government implemented the 'Groups Areas Act 1950, which forcibly removed people [of colour] from areas which were declared white only' (Weber \& Bowers-Du Toit 2018:3). This foundation of violence has spread in different directions, including against girls and women. The author is part of a missional team, InnerCHANGE, which thought about designing a curriculum for its teenagers and youth beneficiaries to empower them to constructively challenge the culture of violence around them.

This research uses grounded theology as a methodology to share about InnerCHANGE teaching. Grounded theology seeks to develop 'a theology of experience and theologies from below' (Stevens 2017:203). Such development happens from practicing what someone believes in. InnerCHANGE wants to develop people of peace in matters of GBV in an emancipatory way. An emancipatory approach puts 'a major emphasis on empowerment' (Swartz 2011:48-49). InnerCHANGE applied the theology of experience by designing a curriculum that could empower teenagers and the youth to fight against GBV as people of peace. The latter are those who commit to act non-violently in all circumstances and to call out any acts of violence. This research identified perpetrators and 
enablers of GBV. The perpetrators are mostly men, whereas the enablers are the realities of the normalisation of violence in our local communities, a negative understanding of power and a lack of participation of the church in fighting this pandemic. It tries to answer this question: how can InnerCHANGE participate in empowering the youth and teenagers in fighting against GBV? InnerCHANGE focuses on enablers of GBV in its teaching and its audience is composed of men and women. The curriculum designed was built from existing academic literature on GBV, biblical passages and observations of the reality of GBV in Soshanguve. This is a small contribution the church could make in building communities of peace that fight against acts of violence from the inside out. The designing process of this curriculum took some ethical considerations.

\section{Ethical considerations}

Before starting to write this research, the author spoke to all the InnerCHANGE beneficiaries and neighbours who have shared their experiences of GBV with the team before. He wanted to share his intention to use their lived experiences of GBV as a resource to empower them and others as people of peace who would stand against any acts of violence. It was important to let these neighbours know that their individual stories of GBV won't be shared in detail. However, the author's interpretation of lessons learned from those stories will be put as themes of the curriculum to be designed. The author spoke to 37 women, 29 adults and 8 teenagers. He also spoke to the involved teenagers' parents or guardians to get their consent. He handed out to all of them a consent letter to be signed. This letter described the purpose of the research. It stated that no body's name will be mentioned in the research. It finally stated that nobody's experience of violence will be mentioned verbatim.

After this process, the author started designing the curriculum around the themes of the normalisation of violence, power and participation as the outcome of his interpretation of enablers of GBV.

\section{Normalisation of violence}

The purpose of this section is to teach the audience to see violence as abnormal and encourage it to be aligned to peace and hope building efforts as a foundation of a good society. The Bible alludes multiple times to the importance of building a strong foundation like in 1 King 5:17 where workers are urged to use good stones so that the temple's foundation can be solid. InnerCHANGE thought that a solid foundation in the fight against GBV could be to challenge the current normalisation of violence in our local community, to share a short history of violence for awareness reasons and to allude to coping mechanisms ordinary people use to survive in a violent culture.

\section{Challenging the normal}

In a township like Soshanguve, violence seems to be a normal expression of grievances or power even though it hurts, destroys or dehumanises others. The danger of this normalisation is that ordinary people easily emulate it. What is experienced in Soshanguve seems to be widespread throughout South Africa. There is a general culture of violence in South Africa that many residents have experienced. South Africa is rated as 'the second most unsafe country out of the 48 countries south of the Sahara' (De Beer 2020:4). Violence seems to be a normal phenomenon around us. Gqola (2007:118) stresses that we can only 'undo it by unmasking the collective denial' of violence amongst us. Many of us know abusers and rapists, but we choose to remain silent. Many of us also know a guy who slapped his girlfriend at a function, a teacher who is involved in a sexual relationship with a learner but we do not call him out for doing something wrong. Some of us seem to enjoy homophobic and misogynist jokes we hear in public spaces. In our local community streets, walking women are constantly whistled at, comments are made about their bodies and some eyes go as far as undressing them. Some cases of GBV have resulted in femicide. A female is killed every $8 \mathrm{~h}$ by her male partner in South Africa. These statistics are 'five times higher than the average in the world' (Banda 2020:1). Moreover, a recent report from the South African Police Services shows that 'sexual crimes' have increased by $1.7 \%$ (873 more cases than in 2019) in 2020 (News24 2020). In the context of Soshanguve, many of these sexual crimes are perpetrated by people who know each other such as neighbours and family members.

The Covid-19 lockdown which the South African government imposed from March 27, 2020, exacerbated the realities of GBV in Soshanguve and countrywide. Tisane (2020:6) points out that ' 87000 gender-based violence complaints were registered within the first three weeks of the lockdown'. Additionally, Google shared that there has been a $64 \%$ spike in online searches for the words 'domestic violence shelters' since the beginning of the lockdown' (Tisane 2020:7).

People of peace need to be aware of these concerning and alarming statistics so that they can become a voice that counters the culture of violence around them. They should constantly seek the peace of their township and city (Jeremiah 29:7) by saying no to violence when they see it. The knowledge of the history of violence in South Africa could also be empowering to people of peace.

\section{A short history of the culture of violence}

InnerCHANGE uses history to help its audience understand the origin of this culture of violence that is around them. According to the Centre for the study of violence and reconciliation (CSVR 2019a), in the 1920s already, cities were facing serious problems of violence. A violent environment was created by the different cultures and customs of migrant labourers colliding as well as the inequalities the capitalist system created. Violence is understood here as 'the intentional use of physical force or power... that either result in or have a high likelihood of resulting in injury, death, psychological harm, maldevelopment, or deprivation' (World Health 
Organization 2020). The 1920s was the season where newly discovered gold mines attracted migrant labours from different corners. Since then, South African cities always have residents from a diversity of cultures and socioeconomic status who sometimes collide. These cities have maintained their violent culture. South Africa still has some of the highest levels of intimate partner homicide in the world, the rate of its child homicide is double the global average and its rate of violence amongst youth is nine times higher than the global average (CSVR 2019b:2). Violence is also on the increase in public protests relating to service delivery, salary demands, vigilantism, demarcation disputes, xenophobic incidents, elections and political party disagreements (CSVR 2019b:3). Hoosen (2020:47-48) stresses that 'apartheid is a legacy that traumatically etched an indelible mark on the psyche of the people of South Africa', which includes an intergenerational culture of violence. The apartheid government focus was on dismantling any movement of insurrection against it. Therefore, it intentionally did not invest in crime prevention in townships. This situation forced township residents to rely on informal mechanisms of justice such as mob justice that are also forms of violence. Mob justice seems to be a way to avenge a crime and establish justice through violence (CSVR 2019a:5-6). Until today, mob justice is still used in our local community.

The unjust system of apartheid also contributed to the internalisation of feelings of inferiority in black people, who are the majority of the population of Soshanguve. Black people were treated as aliens and third-class citizens in their own country. As the author observes many violent incidents in his local community, he has seen a connection 'between feelings of low self-worth and the propensity to violence' (CSVR 2019b:6-7). One of the psychological legacies of apartheid is the inferiority complex that was inculcated in black people. This legacy may 'be a contributing factor to the problem of violence in South Africa' (CSVR 2019:6-7).

Apartheid also brought a culture of fear, mutual suspicion and the need to self-protect. Firearms became a means for self-protection. In our township communities, there was an influx of illegal firearms during the volatile season of the 1980s and 1990s. It is said that many of these firearms were clandestinely imported from neighbouring countries for the liberation movements. Until today, there are still many firearms in civilian hands that 'has an influence on violent crime in South Africa' (CSVR 2019a:7). Many of our neighbours have been held at gunpoint in their neighbourhood. In many house robberies - which occur regularly - perpetrators use guns. This is just an example of how the possession of illegal firearms is common in Soshanguve. This is a reality in many other South African townships. Although this culture of violence has been normalised, it is still unpleasant for many people. This feeling has led them to seek for coping mechanisms.

\section{Coping mechanism}

Violence destroys. Despite the normalisation of violence around us, the majority of our neighbours have learned to cope by building society instead of destroying it. They live in solidarity with one another. They intuitively live out the values of Ubuntu that are 'founded on dialogue, reciprocity... mutual concern, care and sharing' (Mashau \& Kgatle 2019:7). Many of our neighbours belong to societies, neighbourhood watch initiatives and organised special transport as a way to care for one another.

Some neighbours also use destructive means such as alcohol and substance abuse in order to cope with the trauma of living in a violent environment.

\section{Societies}

Societies are groups of people who agree 'to contribute a fixed amount of money to a common pool weekly, fortnightly or monthly' (Nasasa 2020). These contributions can be put towards emergencies such as funerals, an equal share of funds at a certain period, the buying of groceries to be shared by members or the buying of other commonly agreed upon necessities.

Societies are a tangible example of a quest for mutual care. People of peace can be inspired by the society model to work together with like-minded people to fight against pandemics such as GBV. The efforts of people working together to build and protect are seen in our local community in initiatives such as neighbourhood watch.

\section{Neighbourhood watch}

The author believes that 'neighbourhood watch is one of the most effective ways for neighbourhoods to reduce crime' in our local communities (Neighbourhood Watch SA 2020). In the author's neighbourhood, there is also a neighbourhood watch. Every day from 03:00 to 06:00, we hear them blow whistles and horns (vuvuzelas) to communicate with one another to make sure that people and properties are protected. Many neighbours have to start travelling to their workplaces from 03:00. Many of them, especially women, have been victims of violent crimes during those wee hours. Many vulnerable people who are sick have to wake up very early in the morning to go to clinics or hospitals. Many of them have been victims of violence. Because the community established a neighbourhood watch, we have seen violent crime reduction. The patrollers are supported by the community. Each household in the neighbourhood has to contribute R20 monthly that helps pay the patrollers stipends. This is a way our neighbourhood, as well as others, tries to fight against the destruction that violence brings in working towards mutual protection. Ordinary community members also try to protect themselves against violence through communal initiatives such as the special booking of public transport.

\section{Special booking of public transport}

We also see that many of our neighbours, who work outside our community, organise communal public transport to and from work. Often, they have to pay a little bit more than the normal fare so that they can be picked up from their 
homes and dropped off at their homes too. These groups often have to leave the township very early when most people are still sleeping and sometimes return late in the evening. Special bookings have formed communities for mutual protection. As a group, they pose a threat to criminals. The latter find it easy to attach individuals, especially women when they are alone. From pure observation, special transport has reduced a lot of violent crime that many people from the working class as well as school learners were victims of in the wee hours of the morning as well as at night. This is just an example of how working as a group can protect members from violence and other harmful things.

The previous three sections are examples of positive coping mechanisms we see in our local community. Some people choose negative ones such as alcohol and substance abuse.

\section{Alcohol and substance abuse}

This is another coping mechanism many of our neighbours resort to, which is unfortunately negative and sometimes leads to violence. According to Mpani and Nsibande (2015), South Africa has 'the highest level of adult per capita alcohol consumption in Africa'. They add that 'alcohol abuse...is reported to be associated with increased domestic violence' (Mpani \& Nsibande 2015). Gibbs et al. (2020) support this viewpoint in pointing out that alcohol abuse contributes to 'aggression through diminished behaviour inhibition'.

Substance abuse and addiction also seem to be connected to violent behaviours. It is believed that drug and alcohol use can weaken self-control. The effects of substance abuse on someone's behaviour lead 'many to believe that there is a strong correlation between acts of violence and the abuse' (Johnson \& Belfer 1995:115). Another thing that InnerCHANGE believes is that it has enabled GBV in our local community, which has to do with power.

\section{Power}

The purpose of this section is to teach that power is accessible to all. It should be used to serve and uplift others, not to hurt or destroy them. The bible passage Matthew 18:1-4 teaches us that the greatest person in the kingdom of God is the servant not the powerful person with the ability to inflict pain to others without being held accountable. Christians are called to use power, which is a way that empowers others and improves the quality of their lives. It seems that power is often used to suppress or disempower others. Sometimes, negative use of power results in violence. The majority of victims of the latter around us are women and children. In our local community, the systems of power such as patriarchy, culture, law enforcement and money can sometimes be enablers of GBV. A person of peace should learn to critically interact with these systems, draw wisdom from them and reject practices that condone destructive behaviours such as GBV.

\section{Patriarchy}

African societies are patriarchal. This worldview is in sharp contrast with God's creation story in Genesis 1:27 where it is stated that 'God created human beings in his image' (NLT version). In our context, men are seen as 'superior' to women (Wood 2019:2). This sense of superiority has rendered some abusive exercise of power by men, normal. Patriarchy is not limited to Africa; it has 'shaped societies in the history of humanity...it promotes male supremacy' in all spheres of life (Wood 2019:4). This supremacist ideology is 'inherited by men, and it is passed on to them' intergenerationally (Laurien 2004:1). When a woman opposes patriarchy, some 'men resort to coercion, intimidation and violence' (Wood 2019:5).

In a patriarchal society such as South Africa, some men rape women as a means to communicate their power over them. Such was the case with jackrolling, which became common in the township of Soweto in the 1970s and 1980s. 'Jackrolling was a brazen, broad daylight abduction of young women and teenage girls. The perpetrators were militant youths, young men who ruled the streets of the township' (Tlhabi 2017:59). This crime was committed openly without fear of any consequences. This was the beginning of the rape culture South Africa currently decries. Bordie (2020:53-54) traces the beginning of the rape culture in townships from 'the school boycotts that had started after June 1976' during the Soweto uprising. Schools were closed for more than six months because of continued and widespread protests. As a consequence, thousands of learners saw their daily academic obligations interrupted. They stayed at home bored. Newspapers started reporting about learners who turned to drugs and booze and sexual activities. A representative from the South African National Council on Alcoholism said that he estimated that one third of children in Soweto were on drugs or alcohol. These behaviours contributed to violence in general and rape in particular. The Daily News, a newspaper, reported that, between 1976 and 1977, more than three rapes a day were reported in Soweto, and it was believed that the number of unreported rapes meant that the true figure was even higher. The rape culture has spread throughout the country, including Soshanguve. A lesson here is that boredom can lead to harmful things.

There is a general agreement amongst feminist scholars that 'patriarchy is the root cause of violence against women' (Gqola 2015:4). There seems to be a social tolerance of it. Such tolerance legitimates patriarchy and continues to communicate that a woman is not an equal partner of a man in a relationship. Such tolerance should be opposed and rejected by people of peace.

Violence by men against the vulnerable is also sometimes exercised as an attempt to regain power. The post-apartheid South Africa has seen the emancipation of many women. Some of the latter hold better jobs than men. In many households of the township of Soshanguve, women are the only breadwinners. This reality triggers feelings of insecurity 
in some men, which leads to violence. The lack of job or having a less paying job than a woman makes some men feel irrelevant in the domestic sphere. In an attempt to 'regain power', they use violence (Masango 2018:3). Peacock and Levack (2004:12) caution that despite the fact that GBV has reached pandemic levels, 'many men care deeply about the women in the lives'. Such men are an inspiration to people of peace and their behaviour must be emulated. Mshweshwe (2020:4) says that such men 'promote peaceful masculinity' because they view power as a weapon to love, care, protect and emancipate others.

It is important to point out that many women have internalised men's violent behaviours as normal. Banda (2020:4) points out to a survey conducted by Statistics South Africa in 2018 stating that nearly equally both genders agreed that a man can beat his female partner 'for the following reasons': (1) when a woman does not report her whereabouts when she is absent from home, (2) when a woman neglects children, (3) when a woman argues with him, (4) when a woman refuses to have sex and (5) when she burns food. Magezi and Manzanga (2019:2) got almost the same sentiment from both spouses about 'reasons for a man to hit his intimate partner' in the context of Zimbabwe. They added a sixth reason that is infidelity. This endorsement shows the need to include women as people of peace against GBV. Critical interaction with our existing culture could help in this regard.

\section{Culture}

The purpose of this section is to teach that Christians are called to critically interact with the conventional wisdom that culture offers. Principles should be retained that promote human dignity and they should distance themselves from principles that oppress other human beings. Our African culture tends to enable the inequality of power between men and women. This inequality is seen, for instance, how our community values a boy child over a girl child. Boys are seen as heirs of a family. They will keep the surname of the family for life and pass it onto the next generation. Therefore, they are preferred over girls. Girls are expected to join other families when they get married. This preference is unfair because all children are a gift from God who created them in his likeness (Gn 1:27).

Cultural wisdom, sometimes, discourages victims of rape to report the crime to law enforcement officers, especially if perpetrators are family members. Many cases of GBV go unreported because many women conform to the cultural wisdom of keeping the family's dirty laundry in the family. There is, therefore, a 'need to deconstruct' some traditional practices that enable destruction through violence such as rape (Mshweshwe 2020:4). This is also true about a culture that tacitly accepts men's dominance and superiority. This acceptance does not mean that all is well in the relationship between men and women in our community. The reality is that 'women-men relations are tense and suspicious' (Banda 2020:3). Many women are very anxious to cross path with men at night, in the early hours of the morning or on a road less used by many people during the day. A South African woman describes this reality in these words (Gqola 2007):

The Republic of South Africa ... has a contradictory situation where women are legislatively empowered, and yet we do not feel safe in our streets or homes. Truly empowered women do not live with the haunting fear of rape, sexual harassment, smash and grabs and other violent intrusions into their spaces, bodies and psyches. A country that empowers women would grant us our entitlement of freedom of movement, sexual autonomy, bodily integrity and safety. (pp. 116-117)

There is also a corporate culture that prefers to employ men than women. The fact that some women require maternity leave sometimes or are mothers of young children 'discourages some employers from hiring them' because of the disruption that their responsibility may affect the production or work output (Janse van Rensburg, Claasen \& Fourie 2019:7). A job provides a source of income. The latter gives power that could be a good tool to equalise the power relationship between a man and woman in a household and society in general. People of peace should pay attention to all the factors that could contribute to GBV such as employment equity. They should also make themselves aware about the laws of their country so that they can align themselves to the side of justice, which can sometimes mean challenging law enforcement officers. Currently, the rule of law does not always translate into the reign of justice.

\section{Law enforcement for the reign of justice}

The purpose of this section is to show that the best use of power by law enforcement officers should be to protect the victims of violence and ensure that there is consistent consequence management for perpetrators. Unfortunately, from InnerCHANGE experience of reporting cases of GBV, it seems that our police are ill-equipped to diligently deal with such matters. It seems that only $4 \%$ of police officers countrywide have 'the required training about how to deal with domestic and gender-based violence' (Bordie 2020:207). In many instances, when our team took matters to our nearest police station, there was no urgency in comprehensively responding and resolving them. As ordinary community members, we are unaware of the right channels that lead to a successful prosecution of crimes of violence. We expect the police to educate us in that. Yet, we have seen individual police officers giving us different ways to go about one case that have led to unsuccessful prosecutions of the majority of our cases. Our experience has been that 'our police do not have adequate training' in GBV (Davies \& Dreyer 2014:7). The dockets of many cases of GBV have gone missing at our police station (Bordie 2020:75). This reality perpetuates unlawful practices because they result in impunity. It discourages law-abiding residents and people who believe in mob justice may feel vindicated as a result. It has been shown that the rule of law does not always result in the triumph of justice because law-abiding citizens who report to the police cases of GBV don't always get the support they deserve. 
It seems that the inefficiency of the South African police service we have experienced is partly caused by several 'urgent challenges' (Bordie 2020:206). They include a demoralised rank caused by many years of unstable and politically biased senior management. There are still high levels of crime in the country the police have to attend to. Several police officers view GBV as a normal show of power. This is evident in the high number of police officers who have been convicted of crimes related to GBV. It is, however, important to mention that the police have to apply wisdom and diligence in dealing with cases of GBV, particularly cases of rape. There have been cases of women falsely accusing men of rape. The task of the police in these instances was to investigate the matter in order to establish justice. The latter was to restore the reputation of the men implicated as nonrapists. This is one of the ways we have seen them use their power for society building. Another powerful factor that has caused GBV in our local community is money.

\section{Money}

The purpose of this section is to encourage the pursuit of relational equity between a man and women. Someone's ability to financially contribute to the expenses of their relationship could be a springboard towards such equity. In our local community, money is seen as the solution to all problems and the ultimate good quality of life. A longing for the security that money brings influences some relationships. For example, some women are advised to only be in a relationship with financially stable men so that they can be financially supported well. This is a widespread worldview in our local community as well as other African communities. There is a need for women to be 'empowered economically' so that we can start dismantling the existing vertical partnerships we see in relationships and move towards horizontal ones. It is argued that the improvement of women's financial and educational position' is a good recipe for relational equity in households and society (Vähäkangas 2013:86). Financial inequity has led to some cases of GBV in our local community. Some women expect their male partners to be their financial supporters. There are many instances when this expectation leads to violence because a man did not feel that he got a good return on his investment. This mentality of financial expectations from men is also seen in some teenage girls. The latter expect their boyfriends to financially maintain them. The boyfriends also expect something in return that a girl must give. We have seen incidences of GBV when a girlfriend could not give something the boyfriend expected to have as a return for his investment.

It is important to know that women with a source of income have a high chance of negotiating relational equity in a partnership. They are also 'less exposed to domestic violence. [in case of such,] they are more capable of fleeing their abusive partners' and live independently (Chagunda 2019:45).

Our culture of paying a bride price to marry may also be an enabler of power inequity in marriages. Nowadays, the bride price is commercialised. This practice seems to set the tone for the commonly held belief that in a relationship between a man and woman, the man should be the financial supporter and the woman is a servant who takes care of the man's needs. It is also common to see young women who are in intimate partnership with men who are a lot older than them and financially stable so that their material needs can be taken care of. Such an expectation could nurture an inferiority complex and disempower women from their capacity to be 'equal partners in a relationship' and expose them to abuse from men who may have a negative understanding of power (Meyer 2013:11). This mindset could also disempower them from an important role they are already playing in our society. Women are the backbone of the local community life and households. Many of them seem to have a better sense of resilience than men. The author has, for instance, seen many women prematurely getting pregnant, dropping out of school, going back to school after giving birth and getting good-paying jobs as a result of their academic qualifications, whereas many young men who drop out of schools tend not to go back to school and settle for blue-collar jobs. Critical interaction with this concept of power that enables GBV would require the participation of different stakeholders, including the church.

\section{Participation}

InnerCHANGE believes that the church in partnership with local communities should participate in ending GBV. One of the ways to do that is to empower local congregations and communities as people of peace. Local congregations and other faith-based organisations could design teachings on violence so that Christian communities could start exemplifying a new paradigm of building communities of peace. These teachings would help address the negative ramifications of violence our local communities have. Violence has 'far-reaching implications for long-term emotional, behavioural and cognitive adjustment beyond post-traumatic disorder' (Nuttman-Schwartz 2017:30). Violent environments can be traumatic for people and can force them to indulge in destructive behaviours.

Local congregations and other faith-based organisations could encourage people from a young age to form and pursue functional relationships with the other gender. The other gender should be seen as a complement to sustainably build a loving and caring environment, which our world longs for.

Such efforts could prevent GBV in nurturing children, teenagers and the youth as people of peace. They could break the culture of violence we see around us (Hoosen 2020:46-47). Research shows that violence affects children negatively, 'not only during childhood but also into adulthood. When this happens, their relationships, productivity, general conduct and behaviour becomes counterproductive...' (Sifo \& Masango 2014:7). Through these efforts, the church could proactively participate in fighting against GBV. The church is called to 'address human challenges' in order to improve the quality of life of ordinary people (Magezi \& Manzanga 
2019:5). Such a calling means that matters of the common good, everyday concerns and a constant conversation with 'contemporary culture' should preoccupy her (Magezi \& Manzanga 2019:5-6). It could also partner with the United Nations Sustainable Development Goals that 'are targeting eliminating all forms of violence against women' to increase peaceful households and environments (Muluneh et al. 2020:12). The violent culture around us is an inherited practice that is still spreading and infecting people at an alarming proportion. The church is challenged to participate in minimising this spread from this current generation if it hopes to see a society of peace in which GBV will be inexistent soon. Such participation should mobilise both its membership as well as local communities.

\section{Conclusion}

This study shared InnerCHANGE efforts of participation in fighting against GBV. It uses grounded theology as a methodology in an emancipatory way through a curriculum design to teach teenagers and young adults it serves about becoming people of peace. This curriculum was built around the themes of the normalisation of violence, power and participation. It aimed to help break the inter-generational culture of violence we see in our local community and start to build communities filled with people of peace.

\section{Acknowledgements Competing interests}

The author declares that he has no financial or personal relationships that may have inappropriately influenced him in writing this article.

\section{Author's contributions}

K.T.K. is the sole author of this article.

\section{Funding information}

This research received no specific grant from any funding agency in the public, commercial or not-for-profit sectors.

\section{Data availability}

Data sharing is not applicable to this article as no new data were created or analysed in this study.

\section{Disclaimer}

The views and opinions expressed in this article are those of the author and do not necessarily reflect the official policy or position of any affiliated agency of the author.

\section{References}

Amusa, L.B., Bengesai, A.V. \& Khan, H.T., 2020, 'Predicting the vulnerability of women to intimate partner violence in South Africa: Evidence from tree-based machine learning techniques', Journal of Interpersonal Violence 35(17-18), 3167-3677. https://doi.org/10.1177/0886260520960110
Banda, Z.J., 2020, 'A survey on gender-based violence - The paradox of trust between women and men in South Africa: A missiological scrutiny', HTS Teologiese Studies/ women and men in South Africa: A missiological scrutiny', HTS Teologiese
Theological Studies 76(1), a5797. https://doi.org/10.4102/hts.v76i1.5797

Bordie, N., 2020, Femicide in South Africa, Kwela Books, Cape Town.

Centre for the Study of Violence and Reconciliation, 2019a, Research brief: What drives violence in South Africa?, viewed 23 August 2020, from https://media. africaportal.org/documents/What-Drives-Violence-in-South-Africa.pdf.

Centre for the Study of Violence and Reconciliation, 2019b, Why does South Africa have such high rates of violent crimes?, viewed 23 August 2020, from https://css. ethz.ch/en/services/digital-library/publications/publication.html/138057.

Chagunda, C., 2019, 'The South African social grant system: A positive effect on poverty alleviation and unforeseen socio-cultural consequences', Gender and Behaviour 17(4), 14237-14250.

Davies, P.J. \& Dreyer, Y., 2014, 'A pastoral psychological approach to domestic violence in South Africa', HTS Teologiese Studies/Theological Studies 70(3), Art. \#2802, 8 pages. https://doi.org/10.4102/hts.v70i3.2802

De Beer, S.F., 2020, Urban Africa 2050: Imagining theological education/formation for flourishing African cities, Unpublished draft, Pretoria.

Ggola, P.D., 2015, Rape: A South African nightmare, Jacana Media, Johannesburg.

Gibbs, A., Dunkie, K., Ramsoomar, L., Willan, S., Jama Shai, N., Chatterrji, S. et al., 2020 , 'New learning on drivers of men's physical and/or sexual violence against their female partners, and women's experiences of this, and the implication for prevention interventions', Global Health Action 13(1), 1739845. https://doi.org/1 $0.1080 / 16549716.2020 .1739845$

Gqola, P.D., 2007, 'How the "cult of femininity" and violent masculinities support endemic gender based violence in contemporary South Africa', African Identities 5(1), 111-124. https://doi.org/10.1080/14725840701253894

Hoosen, M.P., 2020, Youth and adolescents' perception of violence in post-apartheid South Africa: A systematic review, University of the Western Cape, Cape Town.

Janse van Rensburg, C.C., Claassen, C. \& Fourie, A., 2019, 'The relationship between marital status and employment in South Africa', Journal of Economic and Financia Sciences 12(1), a244. https://doi.org/10.4102/jef.v12i1.244

Johnson, E.M. \& Belfer, M.L., 1995, 'Substance abuse and violence: Cause and consequence', Journal of Health Care for the Poor and Underserved 6(2), 113-121. https://doi.org/10.1353/hpu.2010.0578

Laurien, A., 2004, 'Partiarchy', in G.J. Sorenson \& J.M. Burns (eds.), Encyclopaedia of leadership, 15 September 2007, viewed 04 March 2011, from http://www.sageereference.com/leade.

Magezi, V. \& Manzanga, P., 2019, 'Gender-based violence and efforts to address the phenomenon: Towards a church public pastoral care intervention proposition for community development in Zimbabwe', HTS Teologiese Studies/Theological Studies 75(4), a5532. https://doi.org/10.4102/hts.v75i4.5532

Masango, M.J., 2018, 'Religion, violence and abuse', HTS Teologiese Studies/ Theological Studies 74(3), a5144. https://doi.org/10.4102/hts.v74i3.5144

Mashau, T.D \& Kgatle, M.S., 2019, 'Prosperity gospel and the culture of greed in postcolonial Africa: Constructing an alternative African Christian Theology of Ubuntu', colonial Africa: Constructing an alternative African Christian Theology of
Verbum et Ecclesia 40(1), a1901. https://doi.org/10.4102/ve.v40i1.1901

Meyer, J., 2013, 'Deconstructing masculinity: Dominant discourses on gender, sexuality and HIV and AIDS from the experience of the adolescent male orphan', HTS Teologiese Studies/Theological Studies 69(1), Art. \#1947, 12 pages. https:// doi.org/10.4102/hts.v69i1.1947

Mpani, P.M. \& Nsibande, N., 2015, Understanding gender policy and gender-based violence in South Africa: A literature review, viewed 03 October 2020, from https://www.soulcity.org.za/campaigns/gbv/resources/understanding-genderpolicy-and-gender-based-violence-in-south-africa-a-literature-review.

Mshweshwe, L., 2020, 'Understanding domestic violence: Masculinity, culture, traditions', Heliyon 6(10), e05334. https://doi.org/10.1016/j.heliyon.2020.e05334

Muluneh, M.D., Stulz, V., Francis, L. \& Agho, K., 2020, 'Gender based violence against women in sub-Saharan Africa: A systematic review and meta-analysis of cross-
sectional studies', International Journal of Environmental Research and Public Health 17(3), 903. https://doi.org/10.3390/ijerph17030903

Nasasa, 2020, About stokvels, viewed 19 December 2020, from https://nasasa.co.za/ about-stokvels/.

Neighbourhood Watch SA, 2020, Home page, viewed 19 December 2020, from https://www.neighbourhoodwatchsa.co.za.

News24, 2020, Infographics crime stats 2020: What you need to know, viewed 31 July 2020, from https://www.news24.com/news24/southafrica/news/infographicscrime-stats-2020-what-you-need-to-know-20200731.

Nuttman-Schwartz, O., 2017, 'Children and adolescents facing a continuous security threat: Aggressive behaviour and post-traumatic stress symptoms', Child Abuse and Neglect 69 (2017), 29-39. https://doi.org/10.1016/j.chiabu.2017.04.008

Peacock, D. \& Levack, A., 2004, 'The men as partners program in South Africa: Reaching men to end gender-based violence and promote sexual and reproductive health', International Journal of Men's Health 3(3), 173-188. https://doi. org/10.3149/jmh.0303.173

Sifo, L.G. \& Masango, M.J., 2014, 'The impact of spousal violence on the children: A pastoral care approach', HTS Teologiese Studies/Theological Studies 70(2), Art. \#2044, 7 pages. https://doi.org/10.4102/hts.v70i2.2044

Stevens, B.A., 2017, 'Grounded theology? A call for a community of practice', Practical Theology 10(2), 201-206. https://doi.org/10.1080/1756073X.2017.1308455

Swartz, S., 2011, “Going deep" and "giving back": Strategies for exceeding ethical expectations when researching amongst vulnerable youth', Qualitative Research 11(1), 47-68. https://doi.org/10.1177/1468794110385885

Tisane, L., 2020, Trapped under quarantine: The surge of domestic violence during the COVID-19 pandemic, viewed 17 October 2020, from https://thebestofafrica.org/ content?author $=5 \mathrm{~d} 89 \mathrm{c} 451 \mathrm{dac} 4323 \mathrm{c} 75 \mathrm{c} 735 \mathrm{~b} 3$. 
Tlhabi, R., 2017, Khwezi. The remarkable story of Fezekile Ntsukela Kuzwayo, Jonathan Ball Publishers, Johannesburg.

Vähäkangas, M., 2013, 'Gender, narratives, and religious competition among the Sonjo of Tanzania', Missionalia 41(1), 66-89. https://doi.org/10.7832/41 $1-22$

Weber, S. \& Bowers-DuToit, N., 2018, 'Sexual violence against children and youth Exploring the role of congregations in addressing the protection of young girls on the Cape Flats', HTS Teologiese Studies/Theological Studies 74(3), a5089. https:// doi.org/10.4102/hts.v74i3.5089
Wood, H.J., 2019, 'Gender inequality: The problem of harmful, patriarchal, traditional and cultural gender practices in the church', HTS Teologiese Studies/ Theological Studies 75(1), a5177. https://doi.org/10.4102/hts.v75i1.5177

World Health Organization, 2020, Coronavirus disease (COVID-19) advice for the public, viewed 21 July 2020, from https://www.who.int/emergencies/diseases/ novel-coronavirus-2019/advice-for-public.

Yamile, N., 2020, 'Schoolgirls leading their rural community in dialogue to address gender-based violence', Agenda 35(1), 54-66. https://doi.org/10.1080/10130950. 2020.1845458 